\title{
RESEARCH Note \\ Presence of fin whales (Balaenoptera physalus) in Mejillones Bay, a major seaport area in northern Chile
}

Presencia de ballenas de aleta (Balaenoptera physalus) en bahía Mejillones, un puerto principal en el norte de Chile

\begin{abstract}
Aldo S. Pacheco ${ }^{1}$, Viviana K. Villegas ${ }^{2}$, José M. Riascos ${ }^{1}$ and Koen Van Waerebeek ${ }^{3}$
${ }^{1}$ Instituto de Ciencias Naturales Alexander von Humboldt, Universidad de Antofagasta, CENSOR Laboratory, Climate Change Ecology Group, Av. Universidad de Antofagasta 02800, Antofagasta, Chile. babuchapv@yahoo.com, aldo.pacheco@uantof.cl ${ }^{2}$ Programa Doctorado en Ciencias Aplicadas Mención Sistema Marinos Costeros, Universidad de Antofagasta, Antofagasta, Chile ${ }^{3}$ Centro Peruano de Estudios Cetológicos (CEPEC), Peruvian Centre for Cetacean Research, Lima-20, Perú

Abstract.- In this paper we report the apparently seasonal presence of fin whales in Mejillones Bay $\left(23^{\circ} \mathrm{S}\right)$, in northern Chile. We compiled a total of 19 sightings representing 95 whales, including 2 mother-calf pairs, between July and October 20062014. We observed groups of 1-10 individuals (mean $5 \pm 2.7$ ind.) principally in nearshore waters, 30-1000 $\mathrm{m}$ off the southwestern tip of Mejillones Bay in austral winter/spring. Fin whales came close to, and potentially overlapped with, the main port access routes of large cargo vessels. Information from real-time monitoring of whale presence relayed to Port Authorities is suggested as to avoid collisions.
\end{abstract}

Key words: Balaenoptera physalus, neritic waters, upwelling center, seasonality

\section{INTRODUCTION}

The fin whale, Balaenoptera physalus (Linnaeus, 1758) is categorized as 'Endangered' by the International Union for the Conservation of Nature (IUCN Red List of Threatened Species) $)^{1}$ and is listed on the respective Appendices I of both CITES (Convention on International Trade in Endangered Species of Wild Fauna and Flora) ${ }^{2}$ and CMS (Convention on the Conservation of Migratory Species). In Chile, this species is categorized as 'Critically Endangered' according to the Ministry of Environment (Supreme Decree $41 / 2011)^{3}$. These listings reflect the fin whale's highly vulnerable status due to continuing low global population levels following low post-whaling recovery rates, requiring an international ban in commercial trade (Aguilar 2009). Such delicate status calls for more surveys and an improved reporting effort in order to understand the current population trends and potential new threats to this species. This is particular true for regions such as the Southeast Pacific where research on baleen whales is still limited.

In Chile's exclusive economic zone (E.E.Z.), fin whales have been sighted principally in the oceanic realm (Clarke 1962, Aguayo et al. 1998a, b; Acevedo et al. 2012), while several individuals have also been recorded in neritic

\footnotetext{
${ }^{1}<$ www.iucnredlist.org/details/2478/0>

${ }^{2}<$ www.cites.org/eng/app/appendices.php $>$

${ }^{3}<$ www.mma.gob.cl/clasificacionespecies/index2.htm $>$
}

waters surrounding three coastal islands at $\sim 29^{\circ} \mathrm{S}$ (Capella et al. 1999, Pérez et al. 2006). Apart from these few observations, no further information is published regarding fin whale distribution in Chilean waters during post-ban years. Recently, one of us (A.S.P.) noted the recurrent presence of fin whales in Mejillones Bay $\left(23^{\circ} \mathrm{S}\right.$, Antofagasta Region), a location that supports dense maritime traffic of large cargo vessels due to the mining industry, Chile's main economic activity. According to a global assessment by the Ship Strike Working Group of the International Whaling Commission (IWC), fin whales suffer the highest mortality rate of all cetaceans due to vessel strikes, with the highest number of dead whales stuck on the bow of vessels (Van Waerebeek \& Leaper 2008). The reason why this species is particularly prone to collision remains unclear, but some authors suggest that collisions occur mainly with juvenile individuals which spend more time at the surface and possibly have not yet acquired the necessary experience for avoiding vessels (Panigada et al. 2006). Therefore, it is important to document the presence of this species in areas where the potential for collision is evident. In this study, we report the recurrent, apparently seasonal presence of fin whales in Mejillones Bay. For this aim, we compiled own sightings together with other sources of authenticated information. 


\section{MATERIALS AND METHODS}

Fin whales were sighted in areas surrounding Punta Rieles and Punta Angamos, at the southwestern end of Mejillones Bay (2302.512'S, 70³0.076’ W) (Fig. 1) from 2006 to 2014. The first two sightings occurred circumstantially in 2006 when one of us (A.S.P.) was visiting Punta Rieles for SCUBA diving. No systematic survey effort was conducted between 2007 and 2010; however we compiled opportunistic sighting records of fin whales undertaken by members of the public who regularly visited Punta Rieles and Mejillones Bay, including marine scientists, divers, fishermen, tour operators amongst other locals. Information from such sources was included for analysis only when sightings were positively confirmed as fin whales by photographic evidence, either still or film. During 20112014, the area was monitored by A.S.P. twice per month between September and November, after incidental records suggested these to be the months of highest frequency of occurrence. Visual search effort, aided by 7 x 50 binoculars, was performed from the top of the $\sim 100 \mathrm{~m}$ rocky cliff at Punta Rieles, for 1-3 hours starting at 11:00 h. The size and composition of the group was determined using the following criteria; single, pair, trio or groups of more than three individuals which generally consisted of relatively large animals following a fairly synchronized breathing and swimming pattern. When whales were located nearshore, observers descended to the shoreline to obtain the closest possible photographs.

\section{RESULTS AND DISCUSSION}

A total of 19 confirmed fin whale sightings were gathered for the study period, representing a combined 95 whales (the sum of best estimates). Group size ranged 1-10 individuals (mean, 5; $\mathrm{SD} \pm 2.7 ; \mathrm{N}=19$ ), including 2 mother-calf pairs (Table 1). Fin whales were sighted mainly in September and October. The earliest documented record occurred circumstantially in October 2006 (Table 1) while the latest sighting occurred on 6 September 2014. Fin whales were spotted principally in the nearshore area between Punta Angamos $\left(23^{\circ} 1.636^{\prime} \mathrm{S}\right.$; $\left.70^{\circ} 30.388^{\prime} \mathrm{W}\right)$ and Punta Rieles $\left(23^{\circ} 2.804^{\prime} \mathrm{S}\right.$; $\left.70^{\circ} 29.982^{\prime} \mathrm{W}\right)$ at estimated distances from shore of 30 $1000 \mathrm{~m}$. Inside the study area (Fig. 1) fin whales changed direction frequently in an apparent random fashion while moving close to shore. After ca. 30-120 min the whales left the area consistently by swimming northwards towards open waters. All individuals were positively identified as fin whales by a diagnostic combination of large size, dark grey dorsal coloration, and a prominent dorsal fin that rises at a shallow angle from the rear of the back (Fig. 2). On 16 July 2010, underwater video further confirmed the identity of the species by its asymmetrical coloration, showing a pale lower jaw on the right side and a dark jaw on the left side.

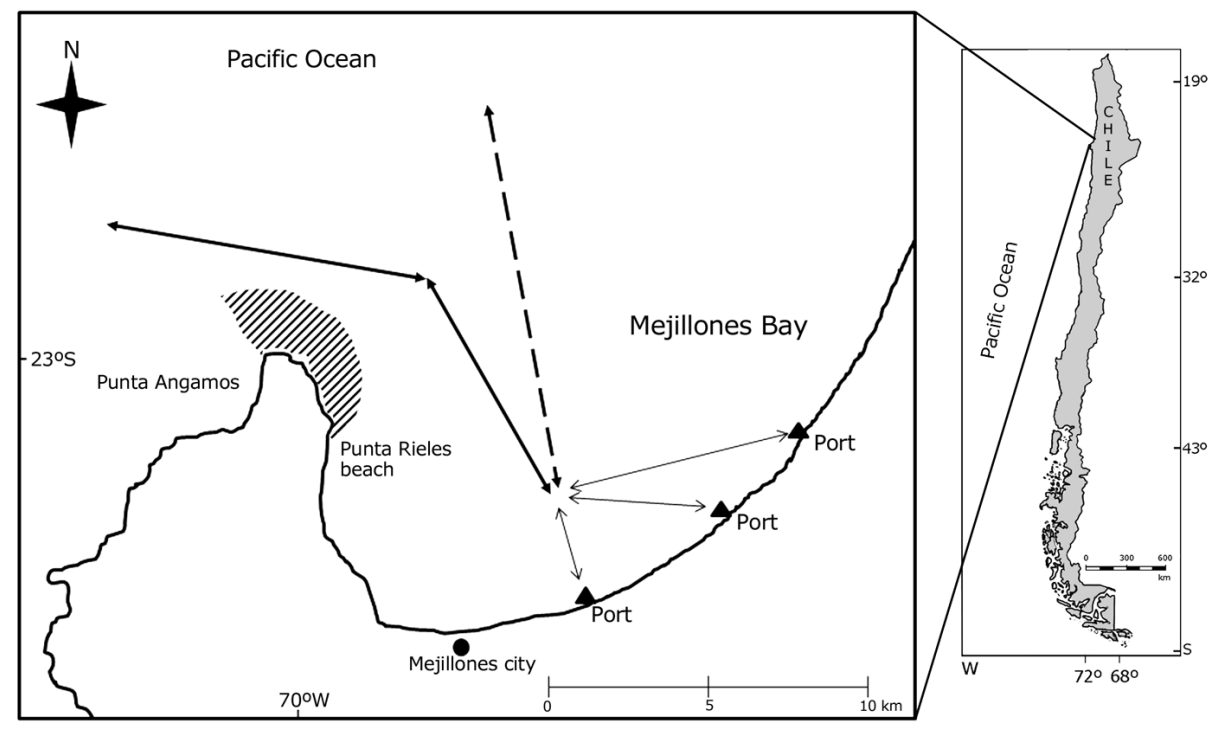

Figure 1. Map of Mejillones Bay in northern Chile. The hatched area represents the location of the sightings of fin whales. The main routes (2) used by large cargo vessels are depicted by continuous and dashed bold lines. Thin arrows represent the routes into the $\mathbf{3}$ main bay ports / Mapa de la bahía Mejillones en el norte de Chile. El área achurada representa la zona de avistamientos de ballenas de aletas. Las principales rutas (2) que toman los barcos cargueros de gran calaje se muestran con flechas continuas y punteadas. Las flechas más delgadas representan las rutas a seguir hacia los 3 puertos principales 


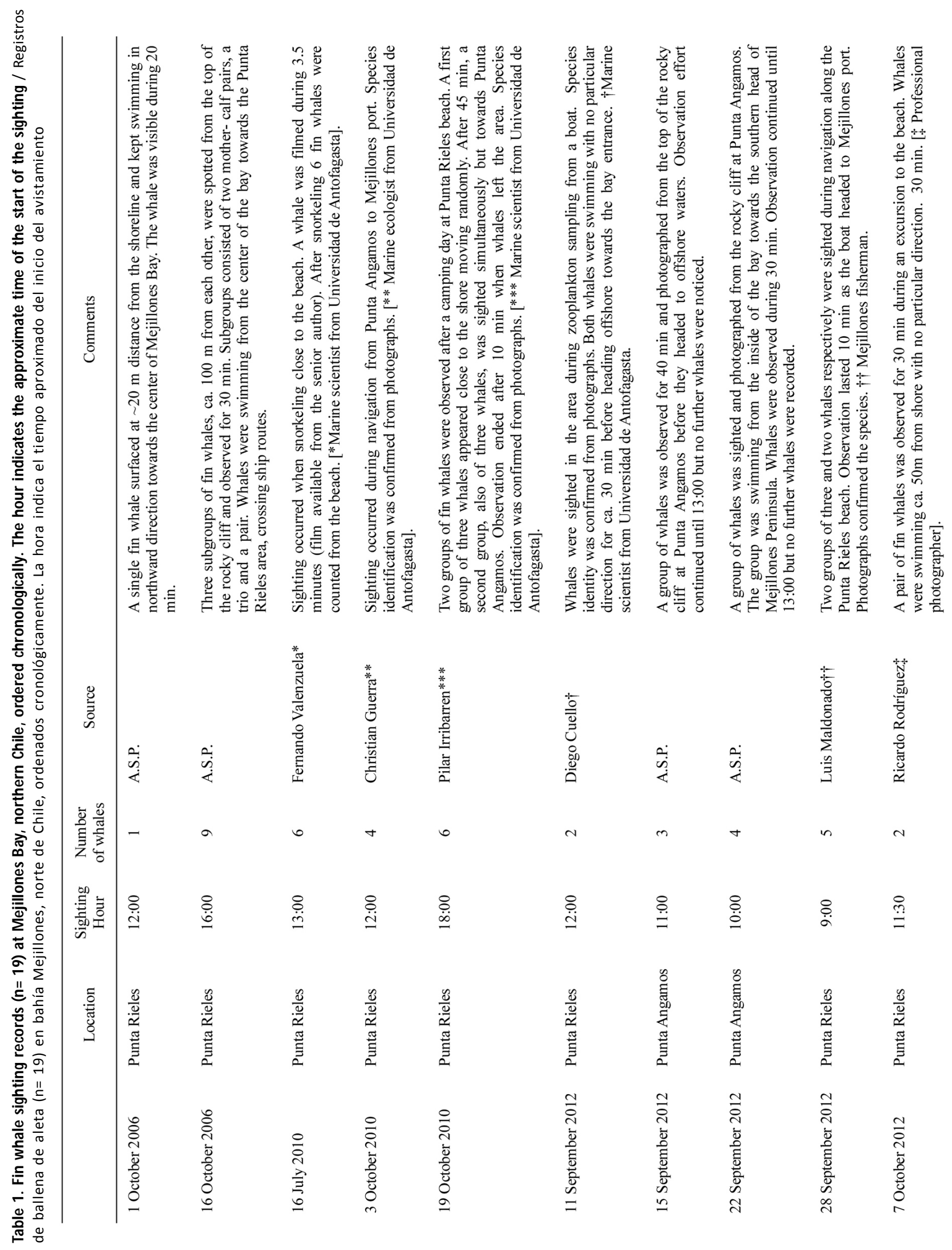

Vol. 50, № 2, 2015 385 


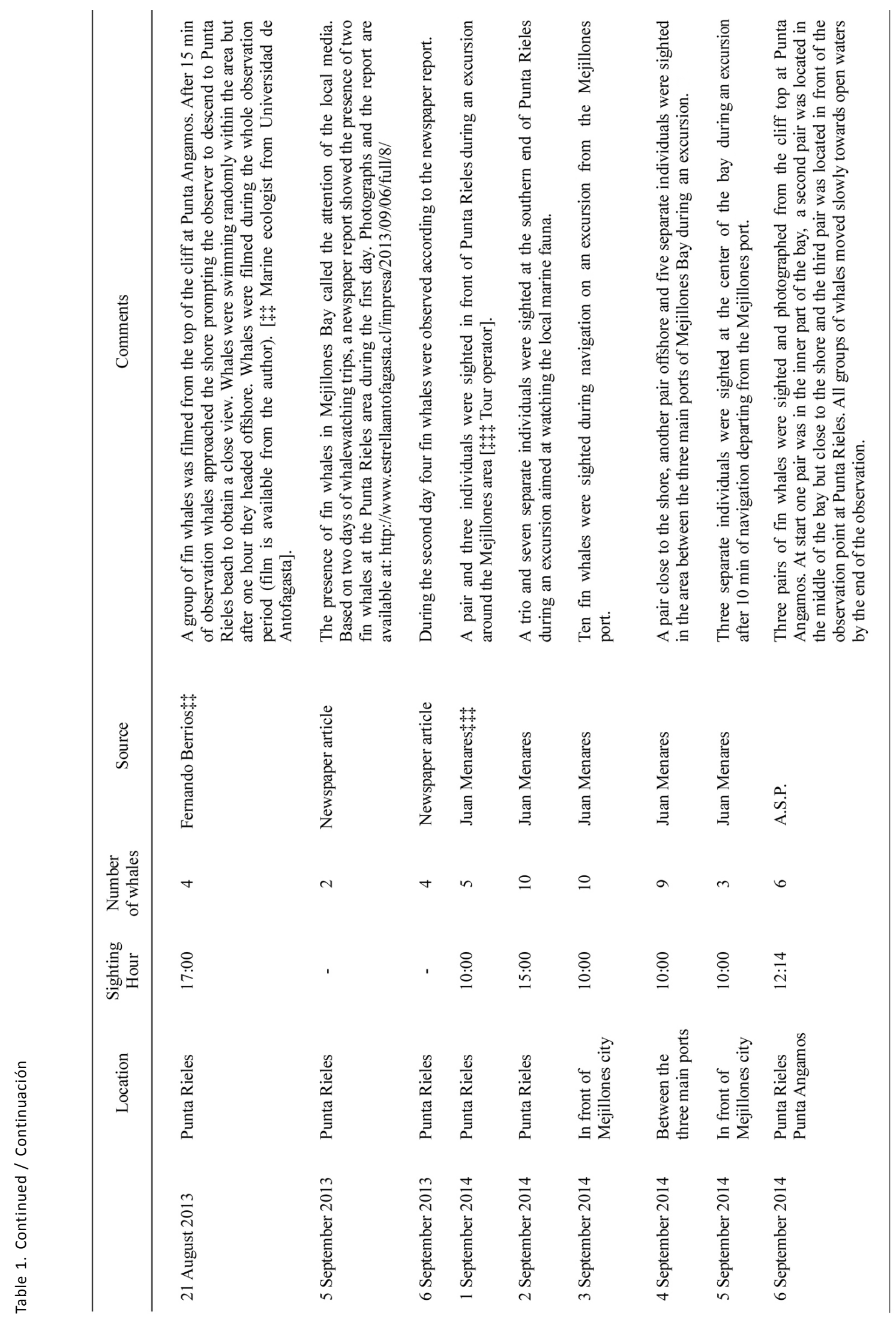



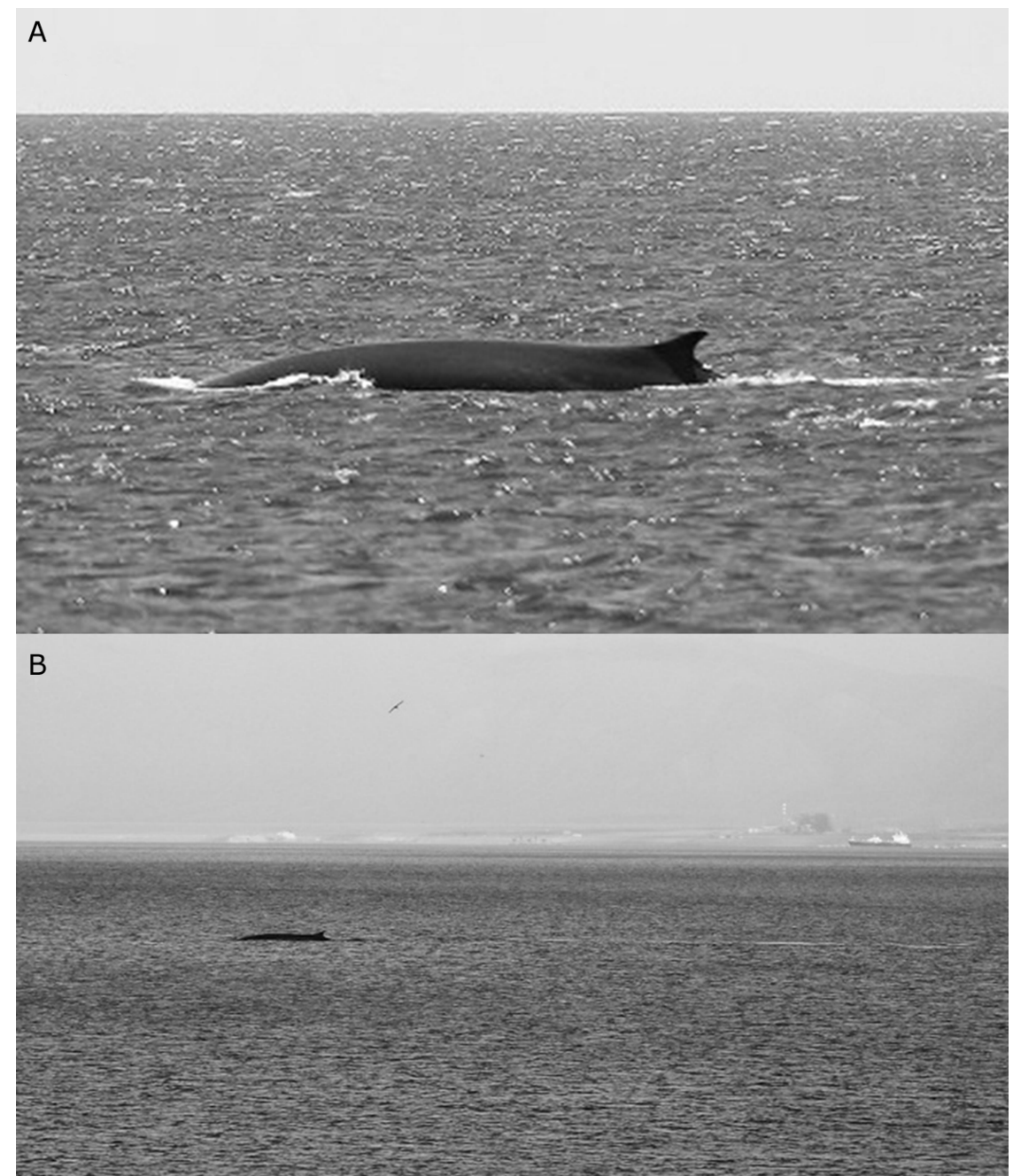

Figure 2. Fin whales in Mejillones Bay, northern Chile. (A) View of the characteristic dorsal fin positioned at a shallow angle towards the rear of the whale's back, on 7 October 2012 (Photo courtesy of Ricardo Rodriguez). (B) View from Punta Rieles beach, a single whale swimming along the shore while in the background a large cargo vessel is loaded at the port (Photo courtesy of Pilar Irribarren) / Ballenas de aleta en la bahía Mejillones, norte de Chile. (A) Vista de la aleta dorsal la cual se posiciona en un ángulo bajo hacia la parte dorsal de la ballena, tomada el 7 de octubre de 2012 (Foto cortesía de Ricardo Rodríguez). (B) Vista desde la playa Punta Rieles, una ballena solitaria se desplaza a lo largo de la costa mientras que en el fondo se aprecia un barco siendo cargado en el puerto (Foto cortesía de Pilar Irribarren)

Whaling and post-whaling data indicated an oceanic distribution of fin whales in Chilean waters (Clarke 1962, Aguayo et al. 1998a, b; Acevedo et al. 2012). This study constitutes the first report of the apparently seasonal occurrence of fin whales in nearshore waters of at least one coastal site in northern Chile. The species has previously been documented during summer in neritic waters surrounding Chañaral, Damas and Choros Islands (centered $\sim 29^{\circ} \mathrm{S}$ ) which are located on the continental shelf relatively close to the coast (5-10 km from the shore), in an area of ca. $50 \mathrm{~m}$ depth (Capella et al. 1999, Pérez et al. 2006, Van Waerebeek et al. 2007). Our results differ from the latter observations because Mejillones Bay is located on the mainland, $680 \mathrm{~km}$ further north and supports intense port activity, while the 3 coastal islands are located within a Marine Protected Area, in a less-populated zone. 
Our data do not yet allow firm conclusions about the seasonal presence of this species in the area, but some points can be raised. Based on observations of fin whale aggregations ranging $287-314 \mathrm{~km}$ off the central coast of Chile $\left(28^{\circ}-36^{\circ} \mathrm{S}\right)$ in October to November 1958 , Clarke (1962) assumed that whales were on their way south towards the Antarctic grounds where they are known to feed on Antarctic krill Euphausia superba, in summer. Clarke (1962) suggested that fin whales may be feeding to some extent during their spring migration towards the Antarctic, so they may depend on some supply of food which is abundant near the boundary regions on the oceanic side of the upwelling currents adjacent to the continental coastlines. However, fin whales may also enter relatively shallow, neritic areas with localized high productivity. Pérez et al. (2006) observed fin whales feeding on the euphausid Euphausia mucronata in the vicinity of the 3 aforementioned coastal islands during the austral summer. Even though we were not able to directly record feeding or the presence of prey in Mejillones Bay, the observed non-directional milling of whales in a circumscribed area was strongly suggestive of feeding behavior. Mejillones Bay and particularly Punta Angamos are located in front of the strongest and most persistent (i.e., year-round) upwelling center in northern Chile (Escribano \& Hidalgo 2000, Escribano et al. 2010), which supports large populations of E. mucronata (Escribano et al. 2000, Antezana 2010). As euphausids constitute the primary prey of fin whales globally (Aguilar 2009) and also in some areas of Chilean waters (Isla Chañaral and Isla Choros-Damas, Marine Protected areas) individuals have been observed feeding on E. mucronata (Pérez et al. 2006) it appears reasonable to hypothesize that this highly productive micro-habitat may serve as a focal feeding ground for the observed fin whales. On the other hand, their nearshore presence in the Mejillones area in September-November theoretically could also be related to calving or breeding and a need for shelter. In the Southern Hemisphere fin whales breed during the austral winter/spring (Aguilar 2009) which coincides with the timing when fin whales were present in our study area. Accordingly, we recorded 2 mother-calf pairs on 16 October 2006 but none stayed there (Table 1). However, fin whales are not known to regularly approach nearshore areas for calving in contrast to 2 other baleen whale species off western South America, i.e., humpback whale Megaptera novaeangliae (Guidino et al. 2014) and southern right whale Eubalaena australis (Aguayo-Lobo et al. 2008). The topographic characteristics of the coast provide possible further explanations (Clarke 1962). The continental shelf off northern and central Chile is very narrow and the slope is very steep (the shelf break is located at $c a .4 \mathrm{~km}$ from the shoreline in front of Punta Angamos) so fin whales may approach the coast while still maintaining great water depth below them or nearby. Further research is necessary to understand the ecological and biological processes behind the probably seasonal presence of fin whales in neritic waters of northern Chile.

Considering that fin whale is the species most commonly involved in collision accidents worldwide (Laist et al. 2001, Panigada et al. 2006, Van Waerebeek \& Leaper 2008), the dense shipping traffic within and around Mejillones Bay may represent a significant threat to fin whales visiting the bay. Our observations indicate that the main aggregation area of the whales lies very close (less than $1000 \mathrm{~m}$ ) to one of the main routes used by large cargo vessels (Fig. 1). Although the normal speed of cargo vessels when maneuvering in the bay (< 10 knots), as reported by Port Authorities (personal communication to A.S.P.) lies within the mostly non-lethal range for whales in case of bow strikes (Van Waerebeek \& Leaper 2008), generating awareness about the presence of the whales with port and other maritime authorities will contribute to their safety and mitigate a potential navigational hazard. During our observations whales moved unpredictably in multiple directions around the bay. When approaching or heading out again to the open ocean many of them likely entered directly into the vessels' paths. Also, while we emphasize the risk with large cargo vessels it is worth noting that this bay is also intensively used by semiindustrial and small-scale artisanal fishing boats and fast recreational boats, further enhancing the risk of collisions. Although the current evidence of danger of collisions in Mejillones Bay is circumstantial, the simultaneous occurrence of fin whales and large numbers of vessels suggest the risk may be significant. We strongly recommend the participation of dedicated land-based observers in direct radio contact with Port Authorities to assist with the monitoring for the presence of fin whales, as well as the provision of real-time information and calls for caution to pilots and captains onboard vessels when entering and exiting Mejillones Bay.

\section{ACKNOWLEDGMENTS}

We warmly thank all the persons who collaborated with this study by sharing information and their photo and video records. Particularly D. Cuello, F. Valenzuela and C. Guerra provided useful material. We are grateful also to 
Under-lieutenant Gerson González of the Capitanía de Puerto de Mejillones, for providing relevant navigational information. Comments by two anonymous reviewers and M.J. Pérez helped us to improve an early version of this manuscript.

\section{LITERATURE CITED}

Acevedo J, M O'Grady \& B Wallis. 2012. Sighting of the fin whale in the Eastern Subtropical South Pacific: Potential breeding ground? Revista de Biología Marina y Oceanografía 47: 559-563.

Aguayo-Lobo A, R Bernal, C Olavarría, V Vallejos \& R Hucke-Gaete. 1998a. Observaciones de cetáceos realizadas entre Valparaíso e Isla de Pascua, Chile, durante los inviernos de 1993, 1994 y 1995. Revista de Biología Marina y Oceanografía 33: 101-123.

Aguayo-Lobo A, D Torres \& J Acevedo. 1998b. Los mamíferos marinos de Chile: 1. Cetacea. Serie Científica INACH 48: 19-159.

Aguayo-Lobo A, J Acevedo, JL Brito, C Olavarria, R Moraga \& C Olave. 2008. Southern right whales, Eubalaena australis (Desmoulins, 1822) off Chile: analyses of records from 1976 to 2008. Revista de Biología Marina y Oceanografía 43: 653-668.

Aguilar A. 2009. Fin whale Balaenoptera physalus. In: Perrin WF, B Würsig \& JGM Thewissen (eds). Encyclopedia of marine mammals, pp. 433-437. Academic Press, San Diego.

Antezana T. 2010. Euphausia mucronata: a keystone herbivore and prey of the Humboldt Current system. Deep Sea Research II 57: 652-662.

Capella J, Y Vilina \& J Gibbons. 1999. Observations of cetaceans at Isla Chañaral and new records at the Humboldt Penguin National Reserve, northern Chile. Estudios Oceanológicos 18: 57-64.

Clarke R. 1962. Whale observation and whale marking off the coast of Chile in 1958 and from Ecuador towards and beyond the Galapagos Islands in 1959. Norsk Hvalfangst Tidende 51: 265-287.
Escribano R \& P Hidalgo. 2000. Spatial distribution of copepods in the north of the Humboldt Current region off Chile during coastal upwelling. Journal of the Marine Biological Association of the United Kingdom 80: 283 290.

Escribano R, VH Marin \& C Irribarren. 2000. Distribution of Euphausia mucronata at the upwelling area of Peninsula Mejillones, northern Chile: the influence of the oxygen minimum layer. Scientia Marina 64: 69-77.

Escribano R, P Hidalgo, M Fuentes \& K Donoso. 2010. Zooplankton time series in the coastal zone off Chile: variation in upwelling and responses of the copepod community. Progress in Oceanography 97-100: 174-186.

Guidino C, MA Llapapasca, S Silva, B Alcorta \& AS Pacheco. 2014. Patterns of spatial and temporal distribution of humpback whales at the southern limit of the Southeast Pacific breeding area. PLoS ONE 9(11): e 112627. <doi:10.1371/journal.pone.0112627>

Laist DW, AR Knowlton, JG Mead, AS Collet \& M Podesta. 2001. Collisions between ships and whales. Marine Mammal Science 17: 35-75.

Panigada S, G Pesante, M Zanardelli, F Capoulade, A Gannier \& MT Weinrich. 2006. Mediterranean fin whales at risk from fatal ship strikes. Marine Pollution Bulletin 52: $1287-1298$.

Pérez MJ, F Thomas, F Uribe, M Sepúlveda, M Flores \& R Moraga. 2006. Fin whales (Balaenoptera physalus) feeding on Euphausia mucronata in nearshore waters off northcentral Chile. Aquatic Mammals 32: 109-113.

Van Waerebeek K \& R Leaper. 2008. Second report of the IWC Vessel Strike Data Standardisation Working Group, 8 pp. Document SC/60/BC5, International Whaling Commision, Scientific Committee, Santiago de Chile.

Van Waerebeek K, AN Baker, F Félix, J Gedamke, GP Sanino, E Secchi, D Sutaria, A Van Helden, M Iñiguez \& Y Wang. 2007. Vessel collisions with small cetaceans worldwide and with large whales in the southern hemisphere, an initial assessment. Latin American Journal of Aquatic Mammals 6: 43-69.

Received 31 January 2015 and accepted 13 May 2015

Associated Editor: María José Pérez Álvarez 